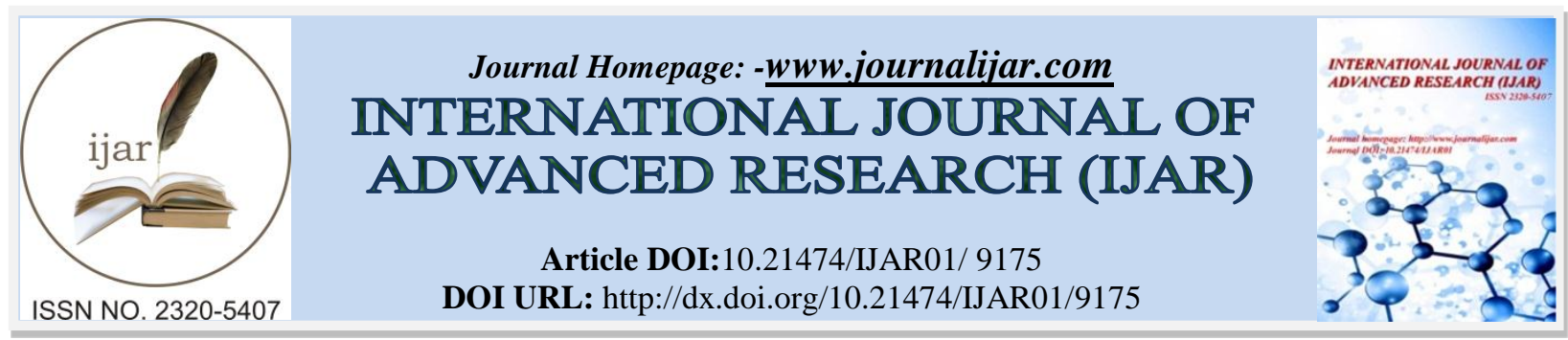

RESEARCH ARTICLE

\title{
DO HUMAN DEVELOPMENT, COMPETITIVE ADVANTAGE, AND HAPPINESS HELP DESCRIBE REGIONAL INCOME?.
}

Tri Prihatini.

Faculty of Economics and Business, Perbanas Institute, Jakarta, Indonesia.

\section{Manuscript Info}

Manuscript History

Received: 26 March 2019

Final Accepted: 28 April 2019

Published: May 2019

Key words:-

Human development, happiness, competitive advantage, regional income.

\section{Abstract}

The study investigates the effect of human development, competitive advantage, and happiness on regional income. By using panel data from 34 provinces in Indonesia, and by using path analysis, the study concluded that, first, human development, and happiness have an effect on competitive advantage, and it shows that human development has a dominant effect on competitive advantage. Second, human development, happiness, and competitive advantage have an effect on regional income, and competitive advantage can be an intervening variable of the effect of human development and happiness on regional income. It is suggested that in order to increase regional income, human development is mandatory. The implication of the study is that the sustainability of human development should be as a main priority to develop all the regions. It seems that the study of the human development will always as an interesting and never ending topic for discussing.

Copy Right, IJAR, 2019,. All rights reserved.

\section{Introduction:-}

The discussion of national competitiveness has been routinely carried out by the World Economic Forum. Likewise, a discussion of the level of happiness and human development is still relevance. All human beings desire to be happy in their lives. All families also want to be happy in their lives. The possibility of residents in a country also wants to be happy. However, the phenomenon shows that the state is more focused on the population in a prosperous country in its life. This is indicated by a measure that is often used to indicate that a country is called successful if the community is prosperous. This measure is commonly called national income. Do people who have high levels of happiness tend to have high levels of income, and vice versa? Do people who have high-income levels also have high levels of happiness, and in vice versa?.

Regional income in Indonesia has always been inequality in the regions. Nevertheless in total, the income has increased from time to time. Judging from the human development index (HDI), the facts show that Indonesia's HDI as a whole is increasing gradually. However, the HDI in each region in Indonesia increased the HDI varied and it appears there is still HDI in heterogeneity, or there is an imbalance in the HDI.

In terms of competitiveness, the phenomenon shows that regional competitiveness in Indonesia is in the heterogeneous category. The same thing happened in the index of happiness (HI) and regional income. The question is whether there is an influence of HDI and HI on the income in Indonesia, and is there an influence of HDI and HI

Corresponding Author:-Tri Prihatini.

Address:-Faculty of Economics and Business, Perbanas Institute. Jakarta, Indonesia. 
on the income through regional competitiveness as an intervening variable? With these backgrounds, this study investigates the effect of HDI and HI on the regional income through regional competitiveness as an intervening variable.

\section{Literature Review}

The discussion on "regional competitiveness" itself produces various definitions, which include the following: Place competitiveness (locality and region) is the ability of the economy and the local (local) community to provide an increase in living standards for residents/residents 4 . Competitiveness is the ability to produce goods and services that meet international testing, and at the same time can maintain a high and sustainable level of income, or the ability of the region to produce high levels of income and employment by remaining open to external competition.

Regional competitiveness can be defined as the ability of constituent members of an area to take action in ensuring that businesses based in the region sell higher levels of value added in international competition, can be maintained by assets and institutions in the region, and therefore contribute on increasing GDP and broader welfare distributions in society, resulting in a high standard of living, as well as the virtuous cycle of learning impact. Regional competitiveness is related to the ability to attract foreign (external) investment and determine its productive role. Urban competitiveness is the ability of an urban area to produce and market its products similar to products from other urban areas 8. Regional competitiveness is the ability of the regional economy to achieve a high and sustainable level of welfare growth while remaining open to domestic and international competition.

From the various definitions, some of the things that we can emphasize are that the competitiveness of the regions will depend on business climate, comparative advantage, and regional competitive advantage. The comparative advantage will be achieved if a country is able to produce more goods and services at a lower cost than other countries. The competitive advantage is more directed at how an area uses its advantages to compete or compete with other regions.

For example, Indonesia and Malaysia both produce coffee and tin. Indonesia is able to produce coffee efficiently and at a low cost but is unable to produce tin efficiently and cheaply. On the contrary, Malaysia is able to produce tin efficiently and at a low cost but is unable to produce coffee efficiently and cheaply. Thus, Indonesia has a comparative advantage in producing coffee and Malaysia has a comparative advantage in producing tin. Trade will be mutually beneficial if both countries are willing to exchange coffee and tin. However, in the framework of world coffee trade, Indonesia's competitive advantage will be greater than Malaysia to compete in the international market. On the contrary in the trade, Malaysia has a better competitive advantage than Indonesia. In the context of regional development, "country" in this concept can be analogous to "region". One thing that can be taken from the concept of comparative and competitive advantage is the importance of effectiveness and efficiency in the production or management of regional resources to increase competitiveness. In this case, then Inter-Regional Cooperation (IRC) can play an important role. Judging from the concept, regional competitiveness will be closely linked to local economic development.

One approach to local economic development is a regional approach, namely how to increase collective efficiency and optimize the use of leverage resources in neighboring regions. Thus, regions can also strengthen competitiveness at a higher level, namely national and global. The efforts of various regions are now to foster cooperation between regions in the promotion of regional potential (regional marketing) is one example of a regional approach.

\section{The concept of happiness}

Basically, the happiness index is a composite index. This composite index is compiled based on 10 (ten) aspects of life that are essential (BPS, 2015). These ten aspects are substantially and jointly reflect a person's level of happiness. Furthermore, it can be said that the level of happiness is the level of satisfaction with 10 aspects of life. The ten aspects are: (1) health, (2) education, (3) work, (4) household income, (5) family harmony, (6) leisure time availability, (7) social relations, (8) conditions houses and assets, (9) environmental conditions, and 10) security conditions. The higher the index value, the higher the level of happiness a person has.

However, a person's happiness is something that is perceived and perceived differently or not always the same. Therefore the level of happiness is something that is subjective. The survey of happiness in 2017 showed that the happiness index reaches 70.69 on a scale of 0 to 100 (bps.go.id). Furthermore, it was presented that the Happiness 
Index of the population living in urban areas tended to be higher than the population living in rural areas, which was 71.64 compared to 69.57 .

The index means that the higher the index value shows the life level of the happier population. Conversely, the lower the index value shows the level of life of the population who are increasingly level of unhappy, the Indonesian Happiness Index in 2017 is a composite index compiled by three dimensions, namely life satisfaction, affect, and the meaning of life. The contribution of each dimension to the Indonesian happiness index is $34.80 \%$ of life satisfaction, $31.18 \%$ of the effect, and $34.02 \%$ of life meanings (bps.go.id). In addition, Frey and Stutzer (2018) stated that happiness can be described through economic condition. Then, the happiness can be stated as economic happiness. This information tells that there are other specific meanings of happiness rather than the tree dimensions.

\section{The concept of regional income}

Welfare has been commonly used to reflect on the economic aspects a person has or the economic aspects achieved by a country. Economic aspects in the State context are indicators of achieving a level of welfare. The size used is Gross Domestic Product per capita.

In the economic field, Case and Fair (2012) stated that gross domestic product (GDP) is the market value of all goods and services produced by a country in a certain period. GDP is one method for calculating national income. At the regional level, gross domestic product is described as a gross regional domestic product. The higher the value, the more prosperous the population in the region is understood.

One important indicator to find out the economic conditions in a region in a given period is the Gross Regional Domestic Product data, both at current prices and at constant prices. Basically is the amount of added value produced by all business units in a particular area, or is the sum of the value of the final goods and services that are not produced by all economic units. On the basis of current prices describe the value added of goods and services calculated using the prevailing prices every year, while on the basis of constant prices indicating the added value of goods and services that are calculated using prices that apply to one particular year as a basis that can be calculated using the base year. On the basis of current prices can also be used to see the shift and economic structure, while constant prices are used to determine economic growth from year to year (Case and Fair, 2012).

Conceptually, human development explains how residents of a region can access the results of development (bps.go.id). Access to human development is obtained from accessing the population in obtaining income, health, education, and others. Human development in Indonesia refers to the United Nations Development Program (UNDP) which is regularly published in the annual Human Development Report (HDR) report which is also presented in the form of an index called the Human Development Index (HDI). In addition, Hasan and Azis (2018) mentioned that economic development in a certain region can be described by human development. The economic development then results the regional income.

\section{Human development}

Bhakti, Istiqomah, and Suprapto, S. (2018) mentioned that there are several factors as indicators of human development. Furthermore, it was said that HDI was formed based on 3 (three) basic dimensions. The three dimensions are (1) long life and healthy life, (2) knowledge, and (3) decent living standards. HDI itself is useful for measuring the success of the development of the quality of human life or the quality of the community/population. HDI also shows the ranking or level of development of a region or country. Furthermore, HDI in Indonesia can be used as a measure of strategic government performance, which then impacts on the determination of the General Allocation Fund.

The meaning of human development has a broad dimension. But basically, human development is the development of the basic dimensions possessed by humans. Furthermore, it was stated that human development will create positive growth in various fields, namely the economic, social, political, cultural, environmental, and changes in the field of human welfare.

Basically, human development will be able to create environmental conditions that enable humans to enjoy longevity, health, and can carry out their lives productively (Human Development Report, 2018). The concept of human development is measured using a basic three-dimensional human approach. These dimensions are longevity and health, knowledge, and a decent standard of living. The dimensions of longevity and health are represented by 
indicators of life expectancy at birth. The knowledge dimension is represented by indicators of old school expectations and an average length of the school. The third dimension is the decent standard of living represented by per capita expenditure. These three dimensions are summarized in a composite index called the Human Development Index (HDI).

Hall \& John F. Helliwell (2014) stated that in general, a country that has a higher human development index, the country has a better life. Life is measured by increasing job satisfaction, the effectiveness of government in running the government and satisfaction in freedom of choice and low inequality in carrying out their work. Furthermore, it is said that life happiness correlates very high with the level of income, supporting the life of social health. However, Blanchflower and Oswald (2005) in Andrew Leigh and Justin Wolfers (2006) convey a paradox that "Happiness and the Human Development Index: The Paradox of Australia", our homeland ranks are very high in the UN Human Development Index (HDI), but her citizens are just not that happy.

Leigh and Olfers (2006) concluded differently from the research of Blanchfloer and Oswald (2005). The results of the study showed that: a modest positive relationship between HDI and happiness, and a stronger positive relationship between HDI and life satisfaction. Similar patterns are found using GDP per capita.

Specifically, Kader Noh (2012) stated that there is a positive correlation between the human development index and gross domestic product. In this study, the human development index is actually placed as the dependent variable for gross domestic product. The results of the study showed that gross domestic product and expenditure for consumption have a positive and significant effect on the human development index in Asian and African countries. However, government expenditure variables have a positive effect on the human development index.

Mellander and Florida (2018) mentioned that there are correlation among human skills, human capital, creativity of people, and regional economic development. Whereas, Pedro, Leitão, and Alves (2018) elaborated that there is the relationship between intellectual capital, as a part of human capability and performance. Furthermore, Pelinescu (2015) stated that there is an impact of human capital on economic growth. Then, the economic growth, in a modern economy, is also resulted from transformation and concentration of intellectual capital (Popkova et al., (2015).

In other study, Prakoso (2018) further analyzed that human development index, regional gross domestic product per capita, and level of open unemployment have effect on poor population. Whereas, Pramartha and Dwirandra (2018) elaborated that there is an effect of fiscal decentralization, capital expenditures, and private investment on the human development index. In addition Shiryaev et al,, (2016) described knowledge economy as a resource for the intensification of the socio-economic transformation of the regional economic space.

Vidotto et al., (2017) stated that basically human capital as an instrument of human development van be measured by using measurement scale which not always be measured by ratio number as general measurement. Furthermore as the general measurement, Wati and Sadjiarto (2019) mentioned that the measurement is using index which calls as human development index. Moreover, it is also mentioned that there is an effect of the human development index and regional income on level of poverty.

\section{Competitive advantage}

Chahal and Bakshi (2015) stated that competitive advantage is a widely concept to elaborate an ability of people or a company to achieve company purpose compare with other company. Furthermore, basically, the competitive advantage is seen from external perspectives. Mora and Barrios (20160 mentioned that there is correlation among brain capital, competitive advantage, and regional economic development. Whereas in the national level, Mačerinskienè and Aleknavičiūtė (2015) elaborated there are several models of national intellectual capital measurements by using comparative measurement models.

Based on the concept of happiness, the concept of regional income, competitive advantage, and the concept of human development, as well as previous research, the research model can be drawn as follows. 
Figure 1:-Research Model

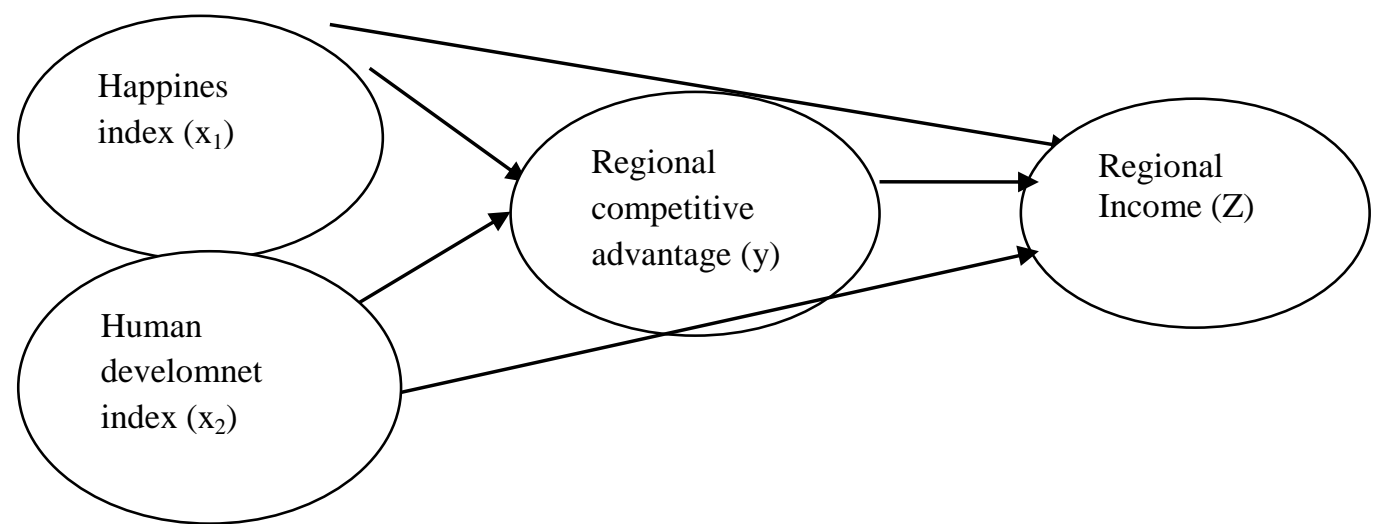

Mathematically the models can be formulated as follows.

$\operatorname{LnY}=\alpha_{0}+\alpha_{1} \operatorname{LnX}_{1}+\alpha_{2} \operatorname{LnX}_{2}+\varepsilon_{1}$

$\operatorname{Ln} Z=\beta_{0}+\beta_{1} X_{1}+\beta_{2} X_{2}+\beta_{3} Y+\varepsilon_{2}$

$\mathrm{X}_{1}=$ happiness level

$\mathrm{X}_{2}=$ level of human development

$\mathrm{Y}=$ regional competitiveness

$\mathrm{Z}=$ regional income per capita

\section{Methods:-}

This research is quantitative research. There are four variables studied in this study. These variables are regional competitiveness, human development index, regional income per capita, and happiness index of Indonesian people's lives. The types of research are applied and causality research. The independent variables in this study are the human development index, and the life happiness index is the dependent variable. Regional income per capita is the dependent variable, and regional competitiveness as an intermediate variable.

\section{Data Sources}

The data used in this study are secondary data about the four variables. The data analyzed were three variables in 34 provinces in Indonesia, namely regional competitiveness, human development index, gross regional domestic product, and life happiness index. Sources of data were extracted and extracted from the pages of the Republic of Indonesia Statistics Agency (BPS, 2018). Data taken is the latest year data from data available, and other data that are adjusted according to consideration of time lag.

\section{Unit of Analysis}

The unit of analysis in this study is the province in Indonesia. There are 34 provinces in Indonesia. However, not all of the 34 provinces were analyzed. This depends on the availability of data in each province. If the data is incomplete in a particular province, then the province is not included in the analysis.

\section{Population and Samples}

The population in this study is 34 provinces in Indonesia. While the sample used is the same as the population. The data analyzed are data from 2014 to 2018. Thus the data is panel data.

\section{Data Collection Methods}

The method of data collection is a statistical document review. Data is extracted, selected and sorted according to data in each province in Indonesia. Not all data from these three variables are available on the BPS page. Only available data is analyzed further. Data collected is in the form of regional competitiveness figures, index data. The index of data are including development index (HDI), Regional income (RI), and happiness index (HI).

\section{Data Analysis Methods}

Data analysis of the research is using panel data regression and path analysis. 
The regression terms are arranged as follows.

$\mathrm{CA}=\alpha_{0}+\alpha_{1}(\mathrm{HDI})+\alpha_{2}(\mathrm{HI})+\varepsilon_{1}$

$\mathrm{RI}=\beta_{0}+\beta_{1}(\mathrm{HDI})+\beta_{2}(\mathrm{CA})+\beta_{3}(\mathrm{HI})+\varepsilon_{2}$

$\mathrm{CA}=$ Regional Competitiveness Advantage

$\mathrm{HI}=$ Happiness Index

HDI = Human Development Index

RI = Regional Gross Regional Domestic Product per capita

The linear regression used in this study is regression using path analysis. Thus the analysis carried out is to calculate the direct influence and indirect influence, as well as the total influence between the independent variables.

The general description of each variable is presented descriptively. This descriptive presentation provides an overview of a collection of provincial clusters that have HDI, RPDB, and I at high, medium and low levels. This clustering method uses a non-hierarchical sampling method, with 3 levels of clusters, namely high, medium and low clusters.

\section{Research results:- \\ Descriptive analysis}

Figure 1:-The cluster of HDI and HI

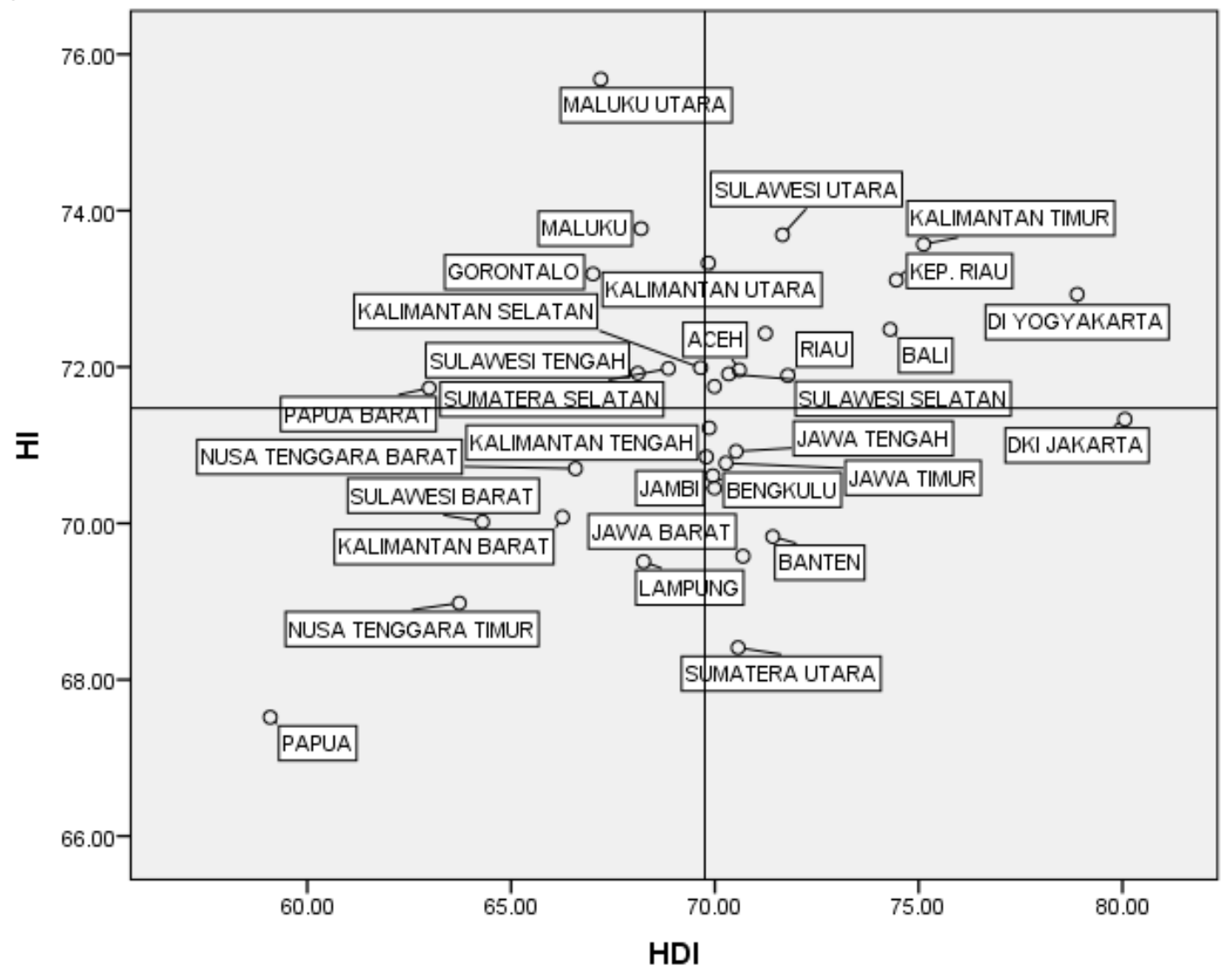

Figure 1 shows that there are 10 regions that have HI and HDI levels above the average. There are 2 regions that are at the average level of HDI and there are two regional areas with an average level of HI. It was further said that there were 8 regions with HI levels below the average, and there were 5 regions with HDI below the average. Then there are 6 regions with HI and HDI levels below the average. Thus HI and HDI in Indonesia tend to be heterogeneous. 
Figure 2:-The cluster of HDI and CA

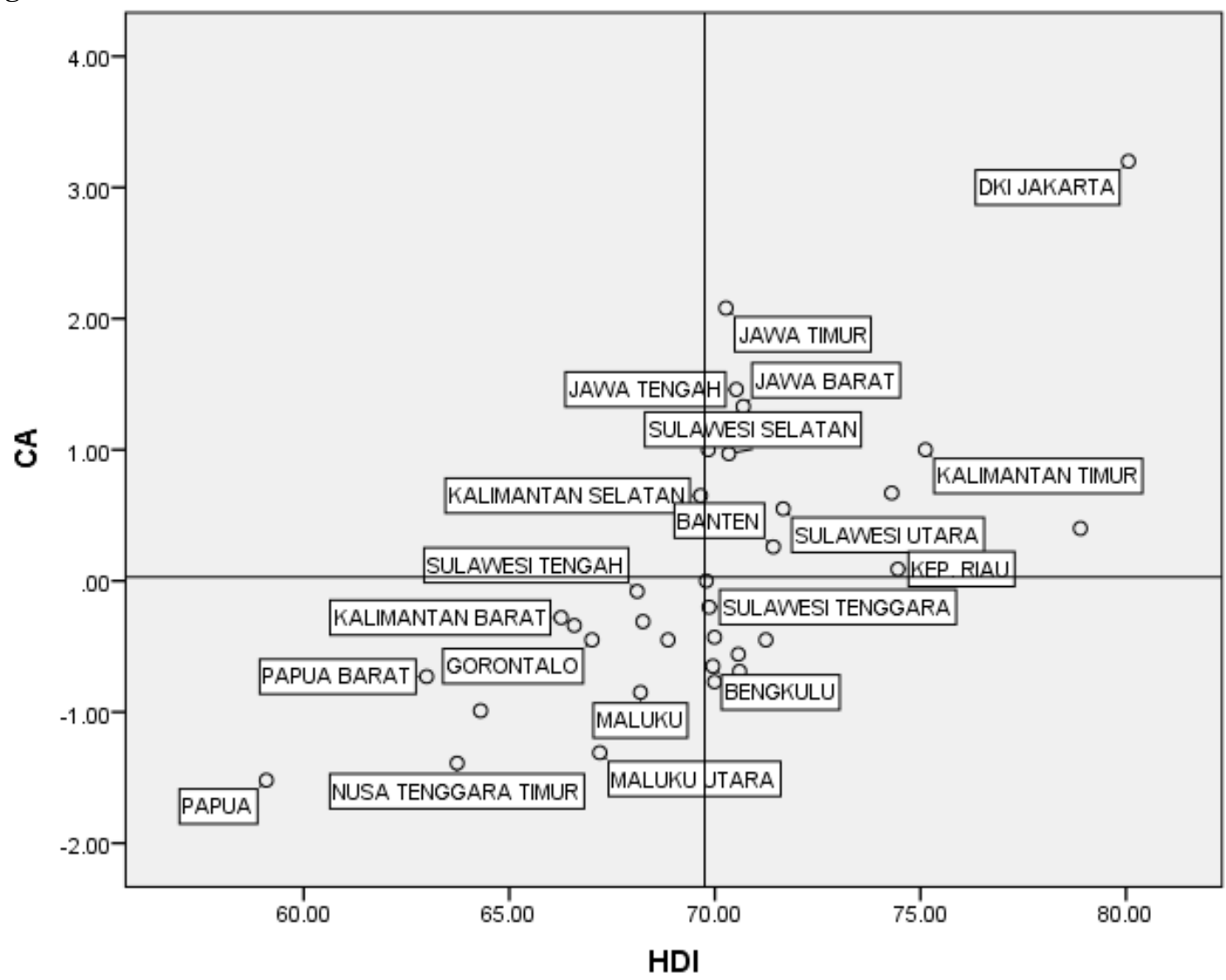

Viewed from the level of CA and HDI, it can be said that 12 regions that have levels of HDI and CA are above average. There are 13 regions with HDI and CA levels below the average. Thus most regions are 21 regions out of 34 regions which have below average competitiveness.

To see statistical homogeneity in each region, cluster analysis is used. By using three clusters, with criteria for high, medium and low-performance areas for the four variables, there were 26 high-performance regions, 3 regions with moderate performance and 5 regions with low performance. For further analysis, the eight regions are not included in the analysis to ensure data homogeneity.

Table 1:-Number of Cases in each Cluster

\begin{tabular}{|l|r|r|}
\hline \multirow{3}{*}{ Cluster } & 1 & 26.000 \\
\cline { 2 - 3 } & 2 & 3.000 \\
\cline { 2 - 3 } & 3 & 5.000 \\
\hline Valid & 34.000 \\
\hline Missing & .000 \\
\hline
\end{tabular}

By using 4 variables analyzed, and by determining 3 clusters, the results show that there are 26 regions in the good cluster, 3 regions in the moderate cluster, and 5 regions in the low cluster. To analyze the influence of the independent variables on the dependent variable, 26 regions were chosen to describe the homogeneity of the data.

Table 2:-Contribution of HDI and HI on CA

\begin{tabular}{|l|l|l|l|l|}
\hline Model & $\mathrm{R}$ & R Square & Adjusted R Square & $\begin{array}{l}\text { Std. The error of the } \\
\text { Estimate }\end{array}$ \\
\hline 1 & $.658^{\mathrm{a}}$ & .432 & .383 & .54192 \\
\hline a. Predictors: (Constant), HDI, HI
\end{tabular}


Table 2 shows that $65.8 \%$ of changes in regional competitiveness can be explained by the variables HDI and HI. The remaining $34.2 \%$ of CA variables are explained by other variables.

Table 3:-Effect of HI and HDI on CA

\begin{tabular}{|c|c|c|c|c|c|c|}
\hline \multicolumn{2}{|c|}{ Model } & \multicolumn{2}{|c|}{ Unstandardized Coefficients } & $\begin{array}{l}\text { Standardized } \\
\text { Coefficients } \\
\text { Beta }\end{array}$ & $\mathrm{t}$ & Sig. \\
\hline \multirow{3}{*}{1} & (Constant) & 8738 & 4.565 & & -1914 & 068 \\
\hline & $\mathrm{HI}$ & .009 & .075 & .021 & .115 & .010 \\
\hline & HDI & .114 & .033 & .646 & 3.478 & .002 \\
\hline
\end{tabular}

From table 3 a regression equation can be arranged, namely $\mathrm{CA}=8.738+0.009 \mathrm{HI}+0.114 \mathrm{HDI}$ with a significance level below 5\%. Thus HI and HDI have a positive effect on CAs, but the influence of HI is far below the influence of HDI on CAs. HI has a career with CA, but the effect is very small and has almost no meaning.

Table 4:-The contribution of CA, HI, and HDI on regional income

\begin{tabular}{|c|c|c|c|c|}
\hline Model & $\mathrm{R}$ & R Square & Adjusted R Square & $\begin{array}{l}\text { Std. An error of the } \\
\text { Estimate }\end{array}$ \\
\hline 1 & $.493^{\mathrm{a}}$ & .243 & .140 & 103154911.39404 \\
\hline
\end{tabular}

From table 4 , it can be informed that $49.3 \%$ changes in regional income can be explained by CA, HDI and Ca. The remaining $50.7 \%$ regional income is explained by other variables.

Table 5:-The effect of HI, HDI, and CA on regional income

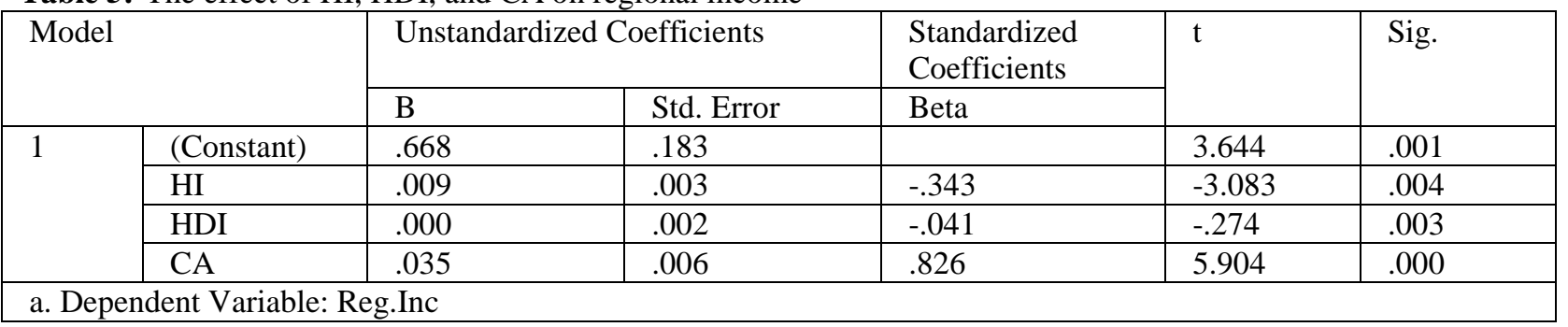

From table 5 , the equation of regression can be compiled that $\mathrm{RI}=0.668+.009 \mathrm{HI}+0.000 \mathrm{HDI}+0.35 \mathrm{CA}$. This equation shows that CA has the largest contribution between HDI and HI, and CA can mediate the influence of HDI and $\mathrm{HI}$ on regional income, with a confidence level of $95 \%$.

\section{Conclusions and recommendations:-}

This study concludes that the level of happiness and the level of human development have a positive effect on the level of regional competition, and the level of human development has a dominant influence on the level of regional competition. Furthermore, it is said that the level of happiness, the level of human development and the level of regional competition had a positive influence on the level of regional income, and the level of regional competition could mediate the level of happiness and level of development on the regional income.

This research suggests that increasing regional income is to increase the level of human development in the regions. The human development in the future will always play very important role in all aspects of human life. The study of the human life will also always as an interesting never ending topic.

\section{References:-}

1. Bhakti, N. A., Istiqomah, I., \& Suprapto, S. (2018). Analysis of Factors Affecting the Human Development Index in Indonesia Period 2008-2012. Equity: Journal of Economics and Finance, 18 (4), 542-469. [Google Scholar]

2. BPS (2018). National Data. http://ipm.bps.go.id/data/nasional, on February 2019.

3. Case, Karl E. dan Ray C. Fair. (2012). Principles of Economics. Eighth Edition, New Jersey: Prentice Hall. 
4. Chahal, H., \& Bakshi, P. (2015). Examining intellectual capital and competitive advantage relationship: Role of innovation and organizational learning. International Journal of Bank Marketing, 33(3), 376-399.

5. Frey, B. S., \& Stutzer, A. (2018). Economics of Happiness. Springer International Publishing.

6. Hall \& John F. Helliwell (2014) Happiness and Human Development. Occasional Paper: United Nations Development Program at Human Development Report.

7. Hasan, M., \& Azis, M. (2018). Economic Development \& Community Empowerment: Human Development Strategies in the Local Economic Perspective. [Google Scholar]

8. Human Development Report, 2018. Human Development Indices and Indicators: 2018 Statistical Update Briefing note for countries on the 2018 Statistical Updatehttp://hdr.undp.org/sites/all/themes/hdr_theme/country-notes/IDN.pdf on March 2019.

9. Leigh, Andrew, and Wolfers, J. (2006). Happiness and The Human Development Index: Australia is not a Paradox. NBER Working Paper Series 11925. http://www.nber.org/papers/w11925 Ntional Bureau of economic research 1050 Massachusetts Avenue Cambridge, MA 02138 January 2006.

10. Kadre, Noh. (2016). Relationship of Human Development Index (HDI) and Gross Regional Domestic Product (GRDP) per Capita in North Maluku Province: An Analysis of the Klassen Typology). Gajah Mada University Thesis. [Google Scholar]

11. Mačerinskienė and Aleknavičiūtè, R. (2015). Comparative evaluation of national intellectual capital measurement models. Business: Theory and Practice, 16, 1.

12. Mellander, C., \& Florida, R. (2018). The rise of skills: Human capital, the creative class, and regional development. Handbook of regional science, 1-13.

13. Mora, F. Q., \& Barrios, M. J. (2016). Brain capital-A competitive advantage for a regional economic development. A practical implementation of model CICBS in Neiva City. Academia y Virtualidad, 6(1), 114136.

14. Mustaqimah, K., Hartoyo, S., \& Fahmi, I. (2018). The Role of Government Capital Expenditures and Human Development Investment in Reducing Poverty in Indonesia. Journal of Development Economics and Policy, 6 (2). [Google Scholar]

15. Pedro, E., Leitão, J., \& Alves, H. (2018). Intellectual capital and performance: Taxonomy of components and multi-dimensional analysis axes. Journal of Intellectual Capital, 19(2), 407-452.

16. Pelinescu, E. (2015). The impact of human capital on economic growth. Procedia Economics and Finance, 22, 184-190.

17. Popkova, E. G., Yurev, V., Stepicheva, O., \& Denisov, N. (2015). Transformation and concentration of intellectual capital as a factor of economic growth in the modern economy. Regional and Sectoral Economic Studies, 15(1), 53-60.

18. Prakoso, D. I. (2018). Analysis of the effect of human development index, regional gross domestic product per capita, and level of open unemployment on poor population in Indonesia 2011 (Doctoral dissertation, University of Muhammadiyah Malang). Unpublished [Google Scholar]

19. Pramartha, I. M. A., \& Dwirandra, A. N. B. (2018). Effect of Fiscal Decentralization, Capital Expenditures, and Private Investment on the Human Development Index. E-Journal of Accounting, 2018 (1), 2458-2482. [Google Scholar]

20. Shiryaev, D. V., Artemova, E. I., Zelinskaya, M. V., Novoselov, S. N., Galiullina, S. D., \& Pismennaya, E. E. (2016). "Knowledge economy" as a resource for the intensification of the socio-economic transformation of the regional economic space. International Review of Management and Marketing, 6(1S), 232-237.

21. Vidotto, J. D. F., Ferenhof, H. A., Selig, P. M., \& Bastos, R. C. (2017). A human capital measurement scale. Journal of Intellectual Capital, 18(2), 316-329.

22. Wati, E., \& Sadjiarto, A. (2019). Effect of Human Development Index and Gross Regional Domestic Product on Poverty. Ecodinamika, 2 (1). [Google Scholar]. 